\title{
Corporate Social Responsibilities of Selected Resorts in Cabanatuan City, Nueva Ecija, Philippines
}

\author{
Jennilyn C. Mina1, Pascuala T. Barlis', Noemi C. Vega1, Gener S. Subia ${ }^{2 *}$ \\ ${ }^{1}$ Nueva Ecija University of Science and Technology, San Isidro Campus, San Isidro, Philippines \\ ${ }^{2}$ Nueva Ecija University of Science and Technology, General Tinio Campus, Cabanatuan City, Philippines \\ Email: *subiagener@yahoo.com
}

How to cite this paper: Mina, J.C., Barlis, P.T., Vega, N.C. and Subia, G.S. (2019) Corporate Social Responsibilities of Selected Resorts in Cabanatuan City, Nueva Ecija, Philippines. Open Access Library Journal, 6: e5292.

https://doi.org/10.4236/oalib.1105292

Received: February 25, 2019

Accepted: March 16, 2019

Published: March 19, 2019

Copyright $\odot 2019$ by author(s) and Open Access Library Inc.

This work is licensed under the Creative Commons Attribution International License (CC BY 4.0).

http://creativecommons.org/licenses/by/4.0/

\begin{abstract}
The management of resorts is not only exerting too much effort in overseeing their business, thinking the new attraction to introduce and making their amenities and facilities even better. Today, they are also focused on performing their Corporate Social Responsibilities. The study presented the Corporate Social Responsibilities of selected resorts in Cabanatuan City. The study aimed to assess different aspects of CSR such as social, ecological and economic aspects of the resorts along with determining the problems that hinder the resorts in doing their Corporate Social Responsibilities. The descriptive method of research was utilized and the normative survey technique was used for gathering data. The questionnaire served as an instrument for collecting data. Randomly selected employees of three selected resorts in Cabanatuan City were taken as respondents. Descriptive statistics such as weighted mean and percentages were the statistical tools used in analyzing and interpreting the research data. Findings showed that in general, employees had assessed their resorts' CSR as evident in terms of social aspect concerning health and safety, ecological and economic aspects. Lack of time, unavailability of technology, lack of fund and lack of employee motivation were identified to be the top problems of resorts' management in doing their CSR programs. It was concluded that the selected resorts in Cabanatuan City have included CSR in their operations. It is recommended that resorts must extend their CSR activities in the community and other stakeholders.
\end{abstract}

\section{Subject Areas}

Managerial Economics 


\section{Keywords}

Social Responsibilities

\section{Introduction}

Resort industry in the Philippines is booming and because it is a tropical country, resorts have a high demand especially during the summer season. In fact, in 2017, the travel and tourism sector contributed a total of P3.35 trillion to the Philippine economy [1]. Vacationists go into places during weekdays and more so on weekends for a lot of reasons such as for recreation, leisure, diversions from the monotony of life, and truly to enjoy the cool rays of the sun during summer time. Some people go to resorts especially during holidays and they prefer to go to those places where they are assured of tight security wherever they go throughout their stay [2].

Resorts are avenue not just for a chance to relax and unwind after working hard [3] but also the best venues for seminars, recollection, debuts and wedding receptions and other special events and occasions. Due to the increasing demand, starting a resort business is a great way to get successful within a short period of time although it requires a huge investment of funds to establish such business [4].

"Cabanatuan City is a 1st class city in the province of Nueva Ecija, Philippines. According to the Census of a population (2015) as cited by the authors in [5], it has a population of 302,231 people, making it the most populous city in Nueva Ecija and the 5th populous in Central Luzon". The city has numerous resorts operating. Some of them are making an impact in the resort industry and becoming a must-see destination by the tourists and sightseers.

It is good to note that these resorts are offering different services to their customers. In addition, they are also paying attention to the welfare of their employees as well as doing their role in conserving the environment, preserving the culture and enhancing the economy. Indeed, these resorts are now equipped with the awareness on the importance of performing their corporate social responsibilities in order for them to succeed. This is also the reason why the tourism and hospitality industry claims to embrace the concept of corporate social responsibility [6]. According to the researchers in [7], "CSR is becoming increasingly important in the corporate world". In particular, companies with bad reputations seem to be interested in changing their negative image through CSR activities [8].

To further validate the importance of such a strategy, CSR has become a mainstay in many corporations' public relations campaign battery. Actually, it has increasingly become an issue in the business world and more and more companies are getting attentive to it. Companies which are engaged in Corporate Social Responsibility would often prefer to claim that they work on sustainable 
development [9]. It seems that CSR is already seen by the companies as a responsibility not imposed by outside forces but dictated by conscience as the best practice of giving back to society, people, communities, and environment and what has been taken from them. What is even more important; companies now have begun to realize the importance of CSR as value addition that might offer them a competitive advantage in their business.

There is growing evidence that a company's CSR activities comprise a legitimate, compelling and increasingly important way to attract and retain good employees [10]. While other companies views that CSR activities have been adopted based on the growing evidence that consumers are willing to give incentives to socially responsible corporations [11].

Numbers of studies about companies' CSR have already been conducted. Despite its growing importance, resort businesses' CSR remains an under-researched area. A study that addresses this research gap is, therefore, necessary hence; the need for this study was realized. It described the CSR of selected resorts in Cabanatuan City in social, economic and ecological aspects. Likewise, this research analyzed the problems that hinder the selected resorts in doing their Corporate Social Responsibilities.

\section{Methodology}

The study used the descriptive method of research in an attempt to analyze and interpret the Corporate Social Responsibility of three Selected Resorts in Cabanatuan City. According to [12], descriptive research is concerned with conditions, practices, structures, differences or relationships that exist, opinions held, processes that are going on or trends that are evidently useful in presenting facts concerning the nature and the status of everything. The respondents of the study were the 47 employees of three selected resorts in Cabanatuan City. The questionnaire was the main instrument used by the researchers in conducting this study. Weighted mean was used to evaluate the assessment of the respondents on the different aspects of Corporate Social Responsibility such as social, ecological and economic aspects of the selected resorts along with determining the problems that hinder the selected resorts in doing their Corporate Social Responsibilities. Statistical tools utilized in this study were frequency, percentage, weighted mean and ranking.

\section{Results and Discussion}

\subsection{Profile of the Respondents}

Most of the resort employees belonged to ages 21 to 30 . Majority of them were male, high school graduates, receiving a monthly salary of P4000 to P5000 and served their companies for less than 10 years. This only denotes that the majority of the resort's employees were male young adults. It is further noticed that the monthly salary of the employees is below the minimum wage of $\mathrm{P} 400.00$ per day for non-agriculture worker (Wage Order No. RBIII-2, 2018). 


\subsection{Corporate Social Responsibilities of Resorts}

\subsubsection{Social}

Item number 6 got the highest weighted mean of 4.04 and was rated "very often" (Table 1). This implies that the management cares for both their employees and customers as they keep their workplaces and machines clean. Furthermore, a clean workplace also ensures the safety and health of employees and visitors which means that workplace injuries can be prevented by taking action to ensure a clean, safe work environment [13]. This also avoids sickness of employees or putting others at risk of illness that can lead to a more productive and efficient performance at work and this can be achieved by ensuring that their work environment is clean [14].

It is very apparent from the results that management of these resorts do not have specific compensation structure as regards to the salaries and wages of their employees since they are not regularly following the regional wage rates. Additionally, employees are sometimes involved in decision-making processes. Notwithstanding the fact that involving employees in the decision-making the process not only empowers them to contribute to the success of an organization but also saves the company time and money, in increased productivity and reduced outsourcing [15].

\subsubsection{Health and Safety}

When it comes to health and safety, items number 2 and 5 got the highest ranks with a weighted mean of 4.81 and 4.68 , respectively and were rated "always" (Table 2). This implies that the water of swimming pools in each resort is changed

Table 1. Corporate social responsibility of the selected resorts (Social Aspect-Employees Welfare).

\begin{tabular}{|c|c|c|c|}
\hline Items & WM & Description & Rank \\
\hline $\begin{array}{l}\text { 1) Management has suitable arrangements for health, safety, } \\
\text { and welfare that provides sufficient protection to its employees }\end{array}$ & 2.83 & Often & 6 \\
\hline $\begin{array}{l}\text { 2) Management provides the employees all necessary benefits } \\
\text { prescribed by the law }\end{array}$ & 2.23 & Sometimes & 8 \\
\hline $\begin{array}{l}\text { 3) Employees are compensated well (follows the regional wage } \\
\text { rates) }\end{array}$ & 2.15 & Sometimes & 9 \\
\hline 4) Management offers training possibilities for employees & 2.68 & Often & 7 \\
\hline $\begin{array}{l}\text { 5) Management has measures to enhance employee } \\
\text { motivation }\end{array}$ & 3.68 & Very Often & 4 \\
\hline 6) Management keeps workplaces and machines clean & 4.04 & Very Often & 1 \\
\hline 7) Employees are involved in decision-making processes & 1.98 & Sometimes & 10 \\
\hline $\begin{array}{l}\text { 8) Management develops incentive structures for } \\
\text { best-performing employees }\end{array}$ & 3.77 & Very Often & 3 \\
\hline 9) Women employees are promoted to management positions & 3.34 & Often & 5 \\
\hline $\begin{array}{l}\text { 10) The management ensures that no form of discrimination, } \\
\text { both in the workplace and at the time of recruitment }\end{array}$ & 3.96 & Very Often & 2 \\
\hline Average Weighted Mean & 3.05 & Often & \\
\hline
\end{tabular}


Table 2. Corporate social responsibility of the selected resorts (Social Aspect-Health and Safety).

\begin{tabular}{|c|c|c|c|}
\hline Items & WM & Description & Rank \\
\hline 1) The resort has safety permits & 3.81 & Very Often & 5.5 \\
\hline 2) The water of swimming pools is changed regularly & 4.81 & Always & 1 \\
\hline 3) A proper amount of chlorine is put in swimming pools & 2.11 & Sometimes & 10 \\
\hline 4) The resort has a sufficient number of well-trained lifeguards & 3.28 & Often & 8 \\
\hline $\begin{array}{l}\text { 5) There are security personnel who is on duty on a } 24 \text {-hour } \\
\text { basis }\end{array}$ & 4.68 & Always & 2 \\
\hline $\begin{array}{l}\text { 6) Management posts sufficient and visible signs in strategic } \\
\text { areas in the swimming pools, to warn guests/customers }\end{array}$ & 3.87 & Very Often & 4 \\
\hline $\begin{array}{l}\text { 7) Adequate first aid medicines and necessary life-saving } \\
\text { equipment are provided within the premises }\end{array}$ & 3.45 & Very Often & 7 \\
\hline $\begin{array}{l}\text { 8) Fire-fighting facilities are provided in accordance with the } \\
\text { Fire Code of the Philippines }\end{array}$ & 2.77 & Often & 9 \\
\hline $\begin{array}{l}\text { 9) Night swimming at pools is allowed only if there are adequate } \\
\text { lifeguards on duty }\end{array}$ & 4.06 & Very Often & 3 \\
\hline $\begin{array}{l}\text { 10) There are separate, clean and well-maintained restrooms for } \\
\text { male and female }\end{array}$ & 3.81 & Very Often & 5.5 \\
\hline Average Weighted Mean & 3.05 & Often & \\
\hline
\end{tabular}

regularly. Aside from the attractiveness, it can create to the customers, cleaning the resorts swimming pool regularly lead to longevity, fewer costly repairs, maintains sanitary and safe water, improves aesthetic, better operation and functionality, develop the value of the resorts and more enjoyment from regular use [16].

The resorts also employ security personnel who are on duty on a 24-hour basis to safeguard the customers as well as the management of the resorts. The reality, people are wanting extra security when it comes to their immediate environment such as in the workplace and even when they are on a vacation in any place [17]. Businesses like resorts have to deal with the fact that theft and other crimes can occur on business premises and guards can be used to prevent crime, maintain security, and assist customers and employees [18].

\subsubsection{Ecological}

Item number 10 got the highest rank with a weighted mean of 4.64 and was rated "always". This shows that there are garbage cans in all activity areas to maintain the cleanliness of the area (Table 3 ). When a business supplies its employees and customers with easy access to waste containers, overall maintenance of the building is made easier and buildings stay cleaner and neater [19].

\subsubsection{Economics}

In the economic aspect of being socially responsible, Items numbers 1 and 2 got the highest ranks with a weighted mean of 5.00, and rated "very often" (Table 4). This shows that the management of the resorts renew their permits and licenses 
Table 3. Corporate Social Responsibility of the Selected Resorts (Ecological Aspect).

\begin{tabular}{|c|c|c|c|}
\hline Items & WM & Description & Rank \\
\hline $\begin{array}{l}\text { 1) Management follows RA } 9003 \text { otherwise known as the } \\
\text { "Philippine Ecological Solid Waste Management Act of 2000" }\end{array}$ & 3.19 & Often & 9 \\
\hline 2) Management follows RA 9275 The Philippine Clean Water Act & 3.45 & Very Often & 6 \\
\hline 3) Management disposes of their water wastes properly & 4.26 & Always & 2 \\
\hline 4) Management disposes of their solid wastes properly & 4.17 & Very Often & 3 \\
\hline $\begin{array}{l}\text { 5) Wastes have been separated as to biodegradable and } \\
\text { non-biodegradable }\end{array}$ & 2.60 & Sometimes & 11 \\
\hline 6) Management utilizes energy saving light pulps & 3.70 & Very Often & 5 \\
\hline 7) Management prohibits smoking at the workplace & 3.32 & Often & 7 \\
\hline $\begin{array}{l}\text { 8) Management uses cleaning procedures with reduced water } \\
\text { consumption }\end{array}$ & 3.98 & Very Often & 4 \\
\hline 9) Management collects recyclable garages for recycling & 3.33 & Often & 8 \\
\hline 10) There are garbage cans in all activity areas & 4.64 & Always & 1 \\
\hline 11) The Management issues an environmental compliance report & 3.09 & Often & 10 \\
\hline Average Weighted Mean & 3.62 & Very Often & \\
\hline
\end{tabular}

Table 4. Corporate Social Responsibility of the Selected Resorts (Economics Aspect).

\begin{tabular}{|c|c|c|c|}
\hline Items & WM & Description & Rank \\
\hline 1) The management renews its permits and licenses & 5.00 & Very Often & 1.5 \\
\hline 2) The management regularly pays its taxes & 5.00 & Very Often & 1.5 \\
\hline $\begin{array}{l}\text { 3) The management provides job opportunities to the } \\
\text { community }\end{array}$ & 2.15 & Sometimes & 4.5 \\
\hline $\begin{array}{l}\text { 4) The management gives regular financial support to } \\
\text { community activities and projects }\end{array}$ & 3.26 & Often & 3 \\
\hline $\begin{array}{l}\text { 5) The management offers training opportunities to people } \\
\text { from the local community }\end{array}$ & 2.15 & Sometimes & 4.5 \\
\hline Average Weighted Mean & 3.51 & Very Often & \\
\hline
\end{tabular}

and at the same time pay their taxes regularly. It is found out that the management of these resorts are complying with the government policies when it comes to renewal of permits and licenses which make their businesses legally operating. Since today it cannot be denied that paying tax is already viewed as an element of corporate responsibility [20], it is clearly part of how business contributes to society where it much consideration as part of the economic dimension, and how companies contribute to the creation of prosperity and to stability in one's economy.

\subsection{Problems that Hinder the Three Selected Resorts in Doing Their Corporate Social Responsibilities}

Item 3 which is lack of time got the highest weighted mean of 4.32 and rated "Always" is the top problem of the resorts in doing their corporate social responsibilities (Table 5). Furthermore, the lack of technology was felt by the employees 
Table 5. Problems Encountered by the Selected Resorts in doing their CSR.

\begin{tabular}{lccc}
\hline \multicolumn{1}{c}{ Item } & WM & Description & Rank \\
\hline 1) Lack of human resources & 3.85 & Very Often & 6 \\
2) Lack of employee motivation & 4.30 & Always & 2 \\
3) Lack of time & 4.32 & Always & 1 \\
4) Unavailability of technology & 4.28 & Always & 3 \\
5) Lack of know-how & 3.72 & Very Often & 7 \\
6) No support from the top-management & 4.00 & Very Often & 5 \\
7) Lack of funds & 4.13 & Very Often & 4 \\
8) No benefits expected from CSR & 3.53 & Very Often & 8 \\
\multicolumn{1}{c}{ Average Weighted Mean } & 4.02 & Very Often & \\
\hline
\end{tabular}

with regards to their compliance with the implementation of CSR. Although there is already a presence of rejuvenation in technology, these resorts in Cabanatuan City have realized the absence of technology was due to lack of funds. Despite doing important work for a company that seemed committed to social responsibility [21], lack of employee motivation to implement CSR seems to be another issue because employees are the soul in the companies' engagement to CSR and their role is very significant to the companies' success in their CSR advocacy.

\section{Conclusions and Recommendations}

The selected resorts often do their part in fulfilling the welfare of their employees as well as in promoting the rich culture and enhancing the economy. Management focuses on keeping their workplaces and machines clean and views that this compliance is major contributors to make their employees more efficient in performing their duties at work. On the other hand, the three selected resorts perform their role in safeguarding the health and safety of both the employees and customers as well as in preserving the environment very often. Additionally, the management realizes the importance of ecological aspects of Corporate Social Responsibility (CSR) where their duties cover all environmental consequences of their company's operations, services, and facilities. However, lack of time and support from top management and unavailability of technology are top problems that hinder the resort in performing their Corporate Social Responsibility.

The researchers suggest that the management of the respondent resorts must continue to assess their level of compliance to Corporate Social Responsibility to attain its sustainability and improve other areas they found missing. Also, the management of the resorts should provide their employees especially those in need of assistance and would want to undergo training to ensure development [22] particularly those who are working as lifeguards and first aiders and the local government must give incentives to all the businesses that are active in doing 
their Corporate Social Responsibilities.

\section{Conflicts of Interest}

The authors declare no conflicts of interest regarding the publication of this paper.

\section{References}

[1] Remo, A.R. (2018) Tourism Still a Bright Spot for PH. https://business.inquirer.net/249613/tourism-still-bright-spot-ph

[2] Travel Bay (2012) Benefits of Going to a Resort for Your Vacation. http://travelbay.org/benefits-of-going-to-a-resort-for-your-vacation

[3] Thomas, S. (2016) Why Do So Many People Like to Travel to Resorts? https://www.quora.com/Why-do-so-many-people-like-to-travel-to-resorts

[4] Swan, J. (2018) How Can I Start Resort Business? https://www.quora.com/How-can-I-start-a-resort-business

[5] Subia, G.S., Amaranto, J.L., Amaranto, J.C., Bustamante, J.Y. and Damaso, I.C. (2019) Chess and Mathematics Performance of College Players: An Exploratory Analysis. Open Access Library Journal, 6, e5195.

https://doi.org/10.4236/oalib.1105195

[6] Cherapanukorn, V. and Focken, K. (2014) Corporate Social Responsibility (CSR) and Sustainability in Asian Luxury Hotels: Policies, Practices, and Standards. Asian Social Science, 10, 198-209. https://doi.org/10.5539/ass.v10n8p198

[7] Holcomb, J., Upchurch, R. and Okumus, F. (2007) Corporate Social Responsibility: What Are Top Hotel Companies Reporting? International Journal of Contemporary Hospitality Management, 19, 461-475. https://doi.org/10.1108/09596110710775129 https://www.researchgate.net/publication/240259792_Corporate_social_responsibili ty_What_are_top_hotel_companies_reporting

[8] Yoon, Y., Canli, Z. and Schwarz, N. (2006) The Effect of Corporate Social Responsibility (CSR) Activities on Companies with Bad Reputations. Journal of Consumer Psychology, 16, 377-390.

https://deepblue.lib.umich.edu/bitstream/handle/2027.42/141315/jcpy377.pdf?seque nce $=1$ \&isAllowed $=\mathrm{y}$

[9] Mina, J.C. and Armas, K.L. (2016) A Critical View on Corporate Social Responsibility in Different Business Environments: A Comparison between Private and Public Banks in Gapan City, Nueva Ecija. North Asian International Research of Multidisciplinary, 2, 1-13.

[10] Bhattacharya, C.B., Sen, S. and Daniel, K. (2008) Using Corporate Social Responsibility to Win the War for Talent. Vol. 49.

https://sloanreview.mit.edu/article/using-corporate-social-responsibility-to-win-the -war-for-talent/

[11] Brown, T.J. and Dacin, P.A. (1997) The Company and the Product: Corporate Associations and Consumer Product Responses. Journal of Marketing, 61, 68-84. https://faculty.fuqua.duke.edu/ moorman/Marketing-Strategy-Seminar-2015/Sessi on\%2012/Brown\%20and\%20Dacin.pdf https://doi.org/10.1177/002224299706100106

[12] Creswell, J.W. (2007) Educational Research, Planning, Conducting and Evaluating Quantitative and Qualitative Research. University of Nebraska, Merril, Prentice 
Hall, Upper Saddle River.

[13] GCA Services Group (n.d.) 6 Reasons Why a Clean Workplace Means a Safe Workplace.

http://www.gcaservices.com/aboutus/news-results/2014/11/19/6-reasons-why-a-cle an-workplace-means-a-safe-workplace

[14] Poss, H. (2018) How Cleanliness Impacts Your Workplace. https://www.actioncleanup.com/blog-4/how-cleanliness-impacts-your-workplace

[15] Anderson, C. (2018) The Advantages of Employee Involvement in Decision Making.

https://smallbusiness.chron.com/advantages-employee-involvement-decision-maki ng-18264.html

[16] Backyard Living Blog (2018) The Importance of Cleaning Your Swimming Pool. https://www.outbackpoolsandspas.com/about/blog/the-importance-of-cleaning-you r-swimming-pool

[17] Inter State Security (2016) What Can Security Guards Do? https://www.interstatesecuritycorp.com/importance-of-security-guard-services/

[18] Kooser, A.C. (n.d.) Benefits of Having a Security Guard at a Business. https://smallbusiness.chron.com/benefits-having-security-guard-business-2386.html

[19] Clean It Supply (2010) The Importance of Trash Cans \& Garbage Cans.

[20] Scheiwiller, T. and Symons, S. (n.d.) Corporate Responsibility and Paying Tax. http://oecdobserver.org/news/archivestory.php/aid/3132/Corporate_responsibility= and_paying_tax.html

[21] Gavett, G. (n.d.) Why Corporate Social Responsibility Doesn't Work. https://hbr.org/2014/04/why-corporate-social-responsibility-doesnt-work

[22] Zabala Jr., B., Gutierrez, M. and Subia, G. (2018) Needs Assessment of Barangay Tanawan, Dingalan, Aurora towards a Proposed Oplan Development Program. International Journal of Environment, Agriculture, and Biotechnology, 3, 2163-2167. https://doi.org/10.22161/ijeab/3.6.28 